\title{
Recent Progress in Stem Cell Therapy for Diabetic Nephropathy
}

\author{
Yang Liu Sydney C.W. Tang \\ Division of Nephrology, Department of Medicine, The University of Hong Kong, Queen Mary Hospital, Hong Kong, \\ SAR, China
}

\section{Key Words}

Diabetic nephropathy · Stem cell therapy · Mesenchymal stem cells · Induced pluripotent stem cells

\begin{abstract}
Background: Diabetic nephropathy (DN) represents the leading cause of end-stage renal disease. Current therapeutic strategies for DN are very limited, and none of them can stop end-stage renal disease progression. Stem cell-based therapy showed encouraging outcomes in kidney disease, including experimental DN. Summary: Both podocytes and proximal tubular epithelial cells play key roles in the pathogenesis of DN and, accordingly, could be regarded as treatment targets. Multiple kinds of stem cells contribute to the regeneration of the injured kidney, including embryonic stem cells (ESCs), mesenchymal stem cells, and induced pluripotent stem cells (iPSCs). Stem cells exert reparatory effects mainly by homing to injured sites, directing differentiation, paracrine action, and immunoregulation. However, poor survival after transplantation under diabetic conditions and unsatisfactory animal models of advanced DN are major obstacles for achieving an efficacious therapeutic effect from stem cell transplantation. Recently, remarkable progress has been made both in the direct differentiation of human ESCs
\end{abstract}

and iPSCs into renal cells and in the generation of tissue- and patient-specific iPSCs, offering a powerful tool to investigate DN mechanisms and to identify the ideal candidate cell for future clinical application. Key Message: This review provides updated information on recent progress and limitations of stem cell-based therapy for DN.

(c) 2015 S. Karger AG, Basel

\section{Introduction}

Diabetes mellitus (DM) is one of the main threats to public health in developed countries. In 2013, more than 382 million people worldwide had DM [1], among which $90 \%$ were of type $2 \mathrm{DM}[2]$. It has been predicted that the number of people with DM will reach 439 million by 2030 , affecting $7.7 \%$ of the world adult population aged 20-79 years [2]. In mainland China and Hong Kong, the estimated comparative prevalence of DM is 9.02 and $7.48 \%$, respectively. Diabetic nephropathy (DN) is one of the most common detrimental complications of diabetes and represents the leading cause of end-stage renal disease [3]. About $25-40 \%$ of patients with diabetes will develop DN. To date, clinical interventions in the treatment of DN are very limited, and none of them can eliminate

\section{KARGER}

E-Mail karger@karger.com

www.karger.com/kdd
(C) 2015 S. Karger AG, Base

2296-9381/15/0021-0020\$39.50/0
Sydney C.W. Tang

Department of Medicine, The University of Hong Kong

Queen Mary Hospital

102 Pokfulam Road, Hong Kong, SAR (China)

E-Mail scwtang@hku.hk 
the development of DN. The current treatment for DN includes full renin-angiotensin system blockade as well as stringent glycemic, lipid, and blood pressure control. However, the number of $\mathrm{DN}$ patients progressing to endstage renal disease and requiring renal replacement therapy has continued to increase, and this imposes enormous medical and socioeconomic burdens [4]. Therefore, there is an urgent need for a regenerative strategy.

Stem cells have shown potential as a therapeutic strategy for DN. Stem cells are an undifferentiated population of cells, capable of self-renewal and differentiation towards one or more lineages to produce specialized cell types. Depending on their origin, stem cells are divided into embryonic stem cells (ESCs), adult stem cells, and induced pluripotent stem cells (iPSCs). In the past years, multiple types of cells have been used in preclinical animal models to repair or regenerate the diabetic kidney. This review summarizes recent progress in stem cell therapy for DN.

\section{Role of Podocytes and Tubular Cells in the Pathogenesis and Regeneration of DN}

\section{Role of Podocytes}

It is now widely recognized that podocytes play a central role in the pathogenesis of $\mathrm{DN}$, which is clinically characterized by progressive proteinuria. Podocytes hold a strategic position and serve as key regulators of solute trafficking between the glomerular and tubulointerstitial compartments of the nephron. Injury to podocytes results in proteinuria and often leads to progression of fibrosis and irreversible renal dysfunction. In DN, podocytes are involved in the development of glomerular hypertrophy, podocytopenia, glomerulosclerosis, and foot process effacement [5]. Loss of podocytes is a hallmark of DN. The number of podocytes is decreased in the glomeruli of patients with type 1 or 2 diabetes, even in diabetics with a short duration of disease $[6,7]$. High extracellular glucose can induce apoptosis in cultured podocytes via reactive oxygen species production and activation of proapoptotic p38 MAPK. In murine type 1 and type 2 diabetic models, apoptosis preceded podocyte depletion, urinary albumin excretion, and mesangial matrix expansion.

Unlike other fast renewing epithelial cells, podocytes have a slow turnover rate and a limited regeneration capacity. Once the podocyte is injured, the glomerular filtration barrier will become leaky, leading to proteinuria which further aggravates podocyte injury. Thus, podocyte injury is a major prognostic determinant in $\mathrm{DN}$.
Therefore, therapies aimed at preventing or limiting podocyte injury and/or at promoting podocyte repair or regeneration have major potential clinical and economic implications [8].

\section{Role of Proximal Tubular Epithelial Cells}

Emerging evidence suggests that proximal tubular epithelial cells (PTECs) play a pivotal role in the pathogenesis of DN [4]. Proteinuria, another hallmark of DN, is already known to activate PTECs to induce tubulointerstitial inflammation and fibrosis via a succession of intracellular events. In DN, tubulointerstitial injury appears early and closely correlates with renal function decline [9]. Infiltrating monocytes, macrophages, and $\mathrm{T}$ cells have been featured predominantly in the interstitium of diabetic kidney disease. We have previously defined tubuloglomerular and glomerulotubular crosstalk pathways [10] and interaction between protein-overloaded PTECs and infiltrating monocytes/T cells [11], supporting the important role of PTECs. In the diabetic milieu, exposure to high glucose, glycated albumin, and advanced glycosylated end product intermediates stimulates a proinflammatory and profibrotic phenotype in PTECs. Besides, targeted proximal tubule injury triggers interstitial fibrosis and glomerulosclerosis [12].

Chronic diabetic kidney disease is characterized by a reduced renal regenerative capacity [13], which is modulated by inflammation [14]. The link between inflammation and regeneration is the sharing of signaling pathways that regulate cell death cell cycle control. With the involvement of Bcl-2, transforming growth factor- $\beta$ (TGF- $\beta$ ), tumor necrosis factor (TNF), Fas ligand, and interferon- $\alpha$ signal pathways, excessive apoptosis of normal glomerular and tubular epithelial cells disrupts the balance between cell proliferation and apoptosis in the early stage of DN, which eventually contributes to the progression of DN. Compared to podocytes, PTECs are believed to have a tremendous capacity for self-renewal. As the key determinant of the development of interstitial inflammation and fibrosis, PTECs might possess a higher potential to serve as an alternative key target in striving for a regenerative approach to DN treatment.

\section{Cell Sources for the Treatment of DN}

\section{Embryonic Stem Cells}

ESCs are pluripotent cells originating from the inner cell mass of the blastocyst [15], which can give rise to the three embryonic germ cell layers. Apart from the highest 
differentiation potential into insulin secreting cells [16, 17], both mouse and human ESCs can be induced to differentiate toward a renal lineage by a panel of defined growth factors or inducers $[18,19]$. By exposure to renal epithelial cell medium supplemented with Matrigel and a combination of defined low concentrations of bone morphogenetic protein-2 (BMP-2) and BMP-7, human ESCs were induced to differentiate into proximal tubular-like cells with expression of aquaporin- 1 confirmed by immunofluorescence and fluorescence-activated cell sorting [19]. Under fully chemically defined monolayer culture conditions composed of BMP-4, activin A, FGF-7, and BMP-7, human ESCs differentiate through posterior primitive streak and intermediate mesoderm as normal nephrogenesis, and, subsequently, the ESC-derived kidney progenitors generate a self-organizing kidney after 3D culture [20]. Nevertheless, the concern of teratoma formation and ethical issues hamper the further clinical application potential of ESCs.

\section{Mesenchymal Stem Cells}

Mesenchymal stem cells (MSCs), also known as mesenchymal stromal cells, are a kind of adult stem cells [21]. Among stem cells, MSCs have several advantages for therapeutic use, such as ease of harvesting, multilineage differentiation potential, potent immunosuppressive effects, safety after infusion of allogeneic cells, and the lack of ethical issues that occur with the application of human ESCs. In the past decades, the therapeutic value of MSCs has been extensively assessed in a broad range of disease models and clinical trials.

MSCs can be isolated from numerous tissues, including bone marrow, adipose tissue [22], umbilical cord blood [23], peripheral blood [24], and amniotic fluid [25]. The richest source for MSCs is bone marrow. MSCs have been shown to differentiate into insulin-secreting cells [26], mesangial cells [27, 28], tubular epithelial cells [29], endothelial cells, and podocytes [30]. The safety and efficacy of allogeneic MSCs in treating acute kidney injury has been assessed in clinical trials and also in open-heart surgery patients who are at high risk of postoperative acute kidney injury $[31,32]$. In preclinical studies, administration of MSCs has also shown potential to treat DN in several animal models. Injection of MSCs into streptozotocin (STZ)-induced type 1 diabetic mice improved renal and pancreatic function $[33,34]$. In NOD/SCID mice, human MSCs decreased mesangial thickening and reduced macrophage infiltration [35]. In a type $1 \mathrm{DN}$ rat model, administration of MSCs ameliorated proteinuria and podocyte injury [36]. Rats treated with MSCs showed a suppressed increase in kidney weight, kidney to body weight index, urinary albumin to creatinine ratio, and an increased creatinine clearance. Furthermore, the MSC treatment reduced the loss of podocytes, effacement of foot processes, widening of foot processes, thickening of the glomerular basal membrane, and loss of glomerular nephrin and podocin. Similar results were reported in rats which received intracardiac infusion of MSCs and cyclosporin [37].

Although MSCs have been widely applied in cell-based therapy, they still have some shortcomings. It has been reported that the MSC preparations from different laboratories or different donors are highly heterogeneous. Cell passage and culture conditions in vitro affect the phenotype of bone marrow MSCs. Furthermore, aging and aging-related disorders significantly impair the survival and differentiation potential of bone marrow MSCs [38-41]. Bone marrow MSCs isolated from chronic heart disease patients and chronic kidney disease rat models displayed a reduced proliferation and differentiation capacity [41-43], limiting their therapeutic efficacy.

\section{Urine-Derived Stem Cells}

Recently, researchers identified a subpopulation of cells isolated from urine that possesses biological characteristics similar to MSCs, namely urine-derived stem cells (USCs) $[44,45]$. A major advantage of using USCs is that these cells can be obtained via a noninvasive, simple, safe, and low-cost procedure. With a higher telomerase activity and longer telomere length compared to other types of MSCs, USCs showed a high self-renewal and proliferation capacity. Upon induction with an appropriate culture condition, USCs can be differentiated into multiple cell lineages. Following implantation in vivo, USCs can form functional urothelial tissue [45]. For treatment of $\mathrm{DN}$, the application of USCs is still at its infancy. Ouyang et al. [46] reported that human USCs genetically modified with fibroblast growth factor 2 (FGF2) relieved type 2 diabetic symptoms in a rat model. However, the role of USCs in the diabetic kidney remains unclear. Further studies need to be conducted.

\section{Induced Pluripotent Stem Cells}

The generation of iPSCs is a milestone in science. By the transduction of four defined transcription factors, namely Oct4, Sox2, Klf4, and c-Myc, terminally differentiated fibroblasts can be reprogrammed into pluripotent stem cells $[47,48]$. The discovery of iPSCs was awarded the Nobel Prize in Medicine in 2012 only 6 years after its initial publication. 
Like ESCs, iPSCs possess a great differentiation capacity. Recently, several promising protocols have been developed to directly differentiate human iPSCs into a renal fate [49-52]. By exposure to serum-free medium supplement with retinoic acid, activin A, and BMP-2 for 4 days, human iPSCs and ESCs differentiated towards ureteric bud progenitor-like cells [49]. Lam et al. [50] reported a highly efficient system to induce human ESCs and iPSCs to differentiate into intermediate mesoderm that subsequently formed renal tubular cells. At the initial step, human iPSCs were induced to differentiate into BRACHYURY+MIXL1+ mesendoderm with nearly $100 \%$ efficiency by treatment with the glycogen synthase kinase- $3 b$ inhibitor CHIR99021. Then, PAX2+LHX1+ cells were generated with 70-80\% efficiency followed by FGF2 and retinoic acid exposure. Upon growth factor withdrawal, these PAX2+LHX1+ cells formed tubular structures that coexpressed proximal tubule markers and kidney-specific protein and partially integrated into embryonic kidney explant cultures. Taguchi et al. [51] established a multistep protocol to differentiate mouse ESCs and human iPSCs into a renal lineage by using a developmental strategy and lineage-tracing method. One study reported the differentiation of human iPSCs into podocyte-like cells [52]. The iPSC-derived cells shared a morphological phenotype analogous with cultured human podocytes following 10 days' treatment with retinoic acid, activin A, and BMP-7 using a combination of embryonic body and monolayer culture condition, and emerging cytoplasmic projection-like foot processes. These cells expressed podocyte markers, including synaptopodin, nephrin, and Wilms tumor protein, but also maintained a proliferative capacity suggestive of a more immature phenotype.

To date, human iPSCs have been generated from multiple sources, including skin fibroblasts, keratinocytes, extraembryonic tissues, cord blood, and peripheral blood cells [47, 53-55]. Studies suggested that tissue-specific iPSCs retain the epigenetic pattern of the original parent cells. Song et al. [56] and Zhou et al. [57, 58] generated iPSCs from normal human kidney mesangial cells and exfoliated renal tubular cells present in urine of healthy donors, respectively, leading the way to developing a tissue-specific iPSC therapy for kidney disease [59]. Moreover, the general reprogramming efficiency from urine was higher than for other methods, between 0.1 and $4 \%$. Apart from tissue-specific iPSCs, many kinds of diseasespecific iPSCs have been produced, including type 1 diabetes $[60,61]$, autosomal-dominant polycystic kidney disease, autosomal-recessive polycystic kidney disease,

Cell Therapy for Diabetic Nephropathy
Wilms tumor, and Alport syndrome [62-64]. The approach can also be applied for DN.

Most interestingly, combining the advantages of iPSCs and MSCs, Lian et al. [65] generated iPSC-derived MSCs (iPS-MSCs). iPS-MSCs can maintain a normal karyotype during culture expansion and constitutively express surface antigens of multipotent MSCs without any obvious loss of self-renewal capacity after 40 passages (120 population doublings). Moreover, like other cells generated from iPSCs [66], iPS-MSCs had a lower gene expression profile on T-cell activation and showed limited or no immune responses upon transplantation in an animal study, which is critical for clinical application. iPS-MSCs have shown therapeutic benefits in animal models of limb ischemia [65], allergic airway inflammation, and periodontitis $[67,68]$. Recently, we established an adriamycin nephropathy model in NOD/SCID mice and found that treatment with iPS-MSCs significantly ameliorated renal dysfunction in adriamycin nephropathy mice. The therapeutic potential of iPS-MSCs for DN is worthy of further exploration.

\section{Major Therapeutic Mechanisms of Stem Cells}

\section{Homing and Direct Differentiation}

Although ESCs and iPSCs are more potent to differentiate into insulin-producing and renal cells in vitro, data on these cells are lacking in animal studies. In STZ-induced type 1 diabetes C57BL/6 mice transplanted with MSCs, evidence indicated that the engrafted MSCs homed to the pancreas and kidney, differentiated into insulinproducing cells in vivo, and prevented the newly generated $\beta$ cells from being destroyed by the immune system [34]. In human MSC-treated NOD/SCID mice, there was an increase in pancreatic islets and $\beta$ cells producing mouse insulin. Human Alu sequences in DNA were detected by PCR assays in the pancreas and kidney on day 17 or 32 after transplantation, but not in other tissues. A few of the human cells appeared to differentiate into glomerular endothelial cells in the glomeruli [35].

\section{Paracrine and Immunomodulation}

It may not be convincing that direct differentiation in vivo could be the dominating repair mechanism as, usually, only a small number of engrafted stem cells were detected in DN animal models. It has been well accepted that stem cells, especially MSCs, benefit the injured kidney mostly via paracrine action and immunomodulation in existing studies. MSCs have the ability to release a wide 
range of trophic and immunomodulatory factors in vitro and in vivo, including vascular endothelial growth factor (VEGF), basic FGF, platelet-derived growth factor (PDGF), insulin-like growth factor-1, hepatocyte growth factor, and epidermal growth factor [69]. Hence, engrafted MSCs might modify the injured kidney by secreting these factors to trigger intracellular signaling in target cells or neighboring cells. We demonstrated that bone marrow MSCs modulate albumin-induced renal tubular inflammation and fibrosis by secreting hepatocyte growth factor and TNF-stimulated gene 6 (TSG-6) both in vitro and in vivo [70]. Conditioned medium of human umbilical cord blood-derived MSCs significantly inhibited $\alpha$-SMA, TGF- $\beta_{1}$, collagen I, and Hsp 47 upregulation and E-cadherin and BMP-7 downregulation induced by TGF- $\beta_{1}$ in NRK-52E cells in a dose-dependent manner through secretion of humoral factors [71]. MSC-transplanted kidneys of type 1 diabetic rats expressed higher levels of BMP-7, indicating that the protective effects of MSCs may be mediated in part by increasing BMP-7 secretion [36]. Through the production of soluble factors, MSCs altered the secretion profile of dendritic cells, resulting in an increased production of the anti-inflammatory cytokine IL-10 and a decreased production of the proinflammatory factors IFN- $\gamma$ and IL-12 [72]. Moreover, MSCs can suppress T-cell proliferation, inhibit proliferation and IgG secretion of B cells, influence dendritic cell maturation, and modulate other immune cells such as natural killer cells and macrophages [73, 74].

\section{Limitations and Challenges}

\section{Stem Cells under Diabetic Conditions}

The microenvironment under diabetic conditions is harsh for stem cells to survive, migrate to the target injured tissue, and exert their reparative functions. It has been found that a reduced synthesis of proteoglycans and glycosaminoglycans in the surrounding tissue results in a reduced proliferation and viability of MSCs in vivo [75]. Also, the production of advanced glycosylated end products inhibited the proliferation of MSCs by activating apoptosis and reactive oxygen species production [76]. In diabetic patients, oxidative stress may also influence the paracrine effects of MSCs under hypoxic conditions. In hypoxic MSCs, high glucose attenuates the production of angiogenic growth factors, including hypoxia-induced factor-1 $\alpha$, VEGF-A, and PDGF-B, by significantly increased intracellular superoxide levels in MSCs [76, 77]. In addition, the migratory capacity of MSCs is also im- paired. Elevated osteoprotegerin in diabetic patients will neutralize the promigratory activity of TNF-related apoptosis-inducing ligand, which promotes the migration of bone marrow stem cells [78, 79]. Indeed, high glucose per se also directly reduces the migration of MSCs [78].

\section{Animal Models of DN}

The National Institute of Health-funded Animal Models of Diabetic Complications Consortium (AMDCC) published as guidelines the following three key criteria for an ideal rodent model of DN [80]: (1) greater than 50\% decline in glomerular filtration rate during the lifetime of the animal; (2) albuminuria (10-fold increase compared with controls), and (3) characteristic pathologic changes including advanced mesangial matrix expansion, any degree of arteriolar hyalinosis, basement membrane thickening, and interstitial fibrosis. Unfortunately, the existing animal models of DN applied for stem cell treatment did not satisfy these criteria. Nonobese and STZ-induced diabetic animals only mimicked the earlier stages of human $\mathrm{DN}$ and infrequently developed features of human advanced $\mathrm{DN}$ [81]. The BTBR ob/ob mouse model of DN comes close to meeting all of the proposed criteria of the AMDCC and offers an alternative option in the future [82].

\section{Conclusions and Future Prospects}

Stem cell-based therapy holds promise for DN treatment. Although kidney-specific stem cells were identified in recent years, the involvement of these stem cells in the regeneration of the kidney was still in doubt [83]. Currently, each type of candidate cell for a cell-based approach has advantages and disadvantages. We need to continue seeking for better ideal cell sources or developing optimized manipulation methods of existing cells. No matter whether targeting podocytes, PTECs, or other cell types in $\mathrm{DN}$, the ideal cell candidate for cell replacement should have the following properties. First, these cells should be easily accessible. Second, they should have a higher survival ability to weather the diabetic stress and the differentiation ability into the desired cell types both in vitro and in vivo. Last, but most crucial for clinical use, there is safety. Although significant advances have been made in generating iPSCs from somatic cells as well as functional kidney cells and tissues from pluripotent stem cells (ESCs and iPSCs), providing a wonderful platform to explore disease mechanisms and potential cell sources, the safety issue remains unsolved. Criteria for the validation of in- 
duced renal progenitor cells need to be established. The tumorigenic property of iPSCs based on viral transduction technology must be eliminated before clinical transplantation. The development of iPSCs without viral vectors might be helpful in the generation of iPSCs from an autologous source [84]. Bone marrow MSCs remain an attractive autologous cell source mainly due to the ease of harvesting and their low immunogenicity. USCs or urinederived iPSCs from DN patients might also serve as suitable cell sources for investigating the pathogenetic mechanisms, screening new treatment, and offering possibilities of future personalized regenerative therapies.

\section{Acknowledgements}

This study was supported by the National Basic Research Program of China 973, program No. 2012CB517600 (No. 2012CB517606), Health and Medical Research Fund of Food and Health Bureau (No. 02132586), Seed Funding Programme for Basic Research (No. 201411159105), Small Project Funding (No. 201309176123) from The University of Hong Kong, and Hong Kong Society of Nephrology Research Grant 2014.

\section{Conflict of Interest Statement}

The authors have no conflicts of interest to declare.

\section{References}

1 International Diabetes Federation: IDF Diabetes Atlas, ed 6 . Brussels, International Diabetes Federation, 2013, pp 33-34. http:// www.idf.org/diabetesatlas.

2 Chen L, Magliano DJ, Zimmet PZ: The worldwide epidemiology of type 2 diabetes mellitus - present and future perspectives. Nat Rev Endocrinol 2012;8:228-236.

-3 Molitch ME, DeFronzo RA, Franz MJ, Keane WF, Mogensen CE, Parving HH, Steffes MW; American Diabetes Association: Nephropathy in diabetes. Diabetes Care 2004;27(suppl 1):S79-S83.

4 Tang SC, Lai KN: The pathogenic role of the renal proximal tubular cell in diabetic nephropathy. Nephrol Dial Transplant 2012;27: 3049-3056.

5 Wolf G, Chen S, Ziyadeh FN: From the periphery of the glomerular capillary wall toward the center of disease: podocyte injury comes of age in diabetic nephropathy. Diabetes 2005;54:1626-1634.

-6 Pagtalunan ME, Miller PL, Jumping-Eagle S, Nelson RG, Myers BD, Rennke HG, Coplon NS, Sun L, Meyer TW: Podocyte loss and progressive glomerular injury in type II diabetes. I Clin Invest 1997;99:342-348.

7 Weil EJ, Lemley KV, Mason CC, Yee B, Jones LI, Blouch K, Lovato T, Richardson M, Myers BD, Nelson RG: Podocyte detachment and reduced glomerular capillary endothelial fenestration promote kidney disease in type 2 diabetic nephropathy. Kidney Int 2012;82:10101017.

8 Mathieson PW: The podocyte as a target for therapies - new and old. Nat Rev Nephrol 2012;8:52-56

-9 Gilbert RE, Cooper ME: The tubulointerstitium in progressive diabetic kidney disease: more than an aftermath of glomerular injury? Kidney Int 1999;56:1627-1637.

10 Tang S, Leung JC, Tsang AW, Lan HY, Chan TM, Lai KN: Transferrin up-regulates chemokine synthesis by human proximal tubular epithelial cells: implication on mechanism of tubuloglomerular communication in glomerulopathic proteinuria. Kidney Int 2002;61: 1655-1665.

11 Lai KN, Leung JC, Chan LY, Guo H, Tang SC: Interaction between proximal tubular epithelial cells and infiltrating monocytes/T cells in the proteinuric state. Kidney Int 2007;71:526538.

12 Grgic I, Campanholle G, Bijol V, Wang C, Sabbisetti VS, Ichimura T, Humphreys BD, Bonventre JV: Targeted proximal tubule injury triggers interstitial fibrosis and glomerulosclerosis. Kidney Int 2012;82:172-183.

13 Papazova DA, Oosterhuis NR, Gremmels H, van Koppen A, Joles JA, Verhaar MC: Cellbased therapies for experimental chronic kidney disease: a systematic review and metaanalysis. Dis Model Mech 2015;8:281-293.

14 Anders HJ: Immune system modulation of kidney regeneration - mechanisms and implications. Nat Rev Nephrol 2014;10:347358.

15 Evans MJ, Kaufman MH: Establishment in culture of pluripotential cells from mouse embryos. Nature 1981;292:154-156.

-16 Lumelsky N, Blondel O, Laeng P, Velasco I, Ravin R, McKay R: Differentiation of embryonic stem cells to insulin-secreting structures similar to pancreatic islets. Science 2001;292: 1389-1394.

17 Jiang W, Shi Y, Zhao D, Chen S, Yong J, Zhang J, Qing T, Sun X, Zhang P, Ding M, et al: In vitro derivation of functional insulinproducing cells from human embryonic stem cells. Cell Res 2007;17:333-344.

18 Kim D, Dressler GR: Nephrogenic factors promote differentiation of mouse embryonic stem cells into renal epithelia. J Am Soc Nephrol 2005;16:3527-3534.

19 Narayanan K, Schumacher KM, Tasnim F, Kandasamy K, Schumacher A, Ni M, Gao S, Gopalan B, Zink D, Ying JY: Human embryonic stem cells differentiate into functional renal proximal tubular-like cells. Kidney Int 2013;83:593-603.
20 Takasato M, Er PX, Becroft M, Vanslambrouck JM, Stanley EG, Elefanty AG, Little MH: Directing human embryonic stem cell differentiation towards a renal lineage generates a self-organizing kidney. Nat Cell Biol 2014; 16:118-126.

21 Pittenger MF, Mackay AM, Beck SC, Jaiswal RK, Douglas R, Mosca JD, Moorman MA, Simonetti DW, Craig S, Marshak DR: Multilineage potential of adult human mesenchymal stem cells. Science 1999;284:143-147.

-22 Zuk PA, Zhu M, Ashijian P, De Ugarte DA, Huang JI, Mizuno H, Alfonso ZC, Fraser JK, Benhaim P, Hedrick MH: Human adipose tissue is a source of multipotent stem cells. Mol Biol Cell 2002;13:4279-4295.

23 Romanov YA, Svintsitskaya VA, Smirnov VN: Searching for alternative sources of postnatal human mesenchymal stem cells: candidate MSC-like cells from umbilical cord. Stem Cells 2003;21:105-110

-24 Chong PP, Selvaratnam L, Abbas AA, Kamarul T: Human peripheral blood derived mesenchymal stem cells demonstrate similar characteristics and chondrogenic differentiation potential to bone marrow derived mesenchymal stem cells. J Orthop Res 2012;30:634642.

25 In 't Anker PS, Scherion SA, Kleijburg-van der Keur C, Noort WA, Claas FH, Willemze R, Fibbe WE, Kanhai HH: Amniotic fluid as a novel source of mesenchymal stem cells for therapeutic transplantation. Blood 2003;102: 1548-1549.

-26 Karnieli O, Izhar-Prato Y, Bulvik S, Efrat S: Generation of insulin-producing cells from human bone marrow mesenchymal stem cells by genetic manipulation. Stem Cells 2007;25: 2837-2844.

27 Imasawa T, Utsunomiya Y, Kawamura T, Zhong Y, Nagasawa R, Okabe M, Maruyama $\mathrm{N}$, Hosoya T, Ohno T: The potential of bone marrow-derived cells to differentiate to glomerular mesangial cells. J Am Soc Nephrol 2001;12:1401-1409. 
-28 Ito T, Suzuki A, Imai E, Okabe M, Hori M: Bone marrow is a reservoir of repopulating mesangial cells during glomerular remodeling. J Am Soc Nephrol 2001;12:2625-2635.

-29 Poulsom R, Forbes SJ, Hodivala-Dilke K, Ryan E, Wyles S, Navaratnarasah S, Jeffery R, Hunt T, Alison M, Cook T, et al: Bone marrow contributes to renal parenchymal turnover and regeneration. J Pathol 2001;195:229-235.

30 Prockop DJ: Repair of tissues by adult stem/ progenitor cells (MSCs): controversies, myths, and changing paradigms. Mol Ther 2009; 17:939-946.

-31 Togel FE, Westenfelder C: Kidney protection and regeneration following acute injury: progress through stem cell therapy. Am J Kidney Dis 2012;60:1012-1022.

-32 Togel FE, Westenfelder C: Mesenchymal stem cells: a new therapeutic tool for AKI. Nat Rev Nephrol 2010;6:179-183.

-33 Ezquer ME, Ezquer FE, Arango-Rodriguez ML, Conget PA: MSC transplantation: a promising therapeutic strategy to manage the onset and progression of diabetic nephropathy. Biol Res 2012;45:289-296.

-34 Ezquer FE, Ezquer ME, Parrau DB, Carpio D, Yanez AJ, Conget PA: Systemic administration of multipotent mesenchymal stromal cells reverts hyperglycemia and prevents nephropathy in type 1 diabetic mice. Biol Blood Marrow Transplant 2008;14:631-640.

>35 Lee RH, Seo MJ, Reger RL, Spees JL, Pulin AA, Olson SD, Prockop DJ: Multipotent stromal cells from human marrow home to and promote repair of pancreatic islets and renal glomeruli in diabetic NOD/scid mice. Proc Natl Acad Sci USA 2006;103:17438-17443.

-36 Wang S, Li Y, Zhao J, Zhang J, Huang Y: Mesenchymal stem cells ameliorate podocyte injury and proteinuria in a type 1 diabetic nephropathy rat model. Biol Blood Marrow Transplant 2013;19:538-546.

-37 Zhou H, Tian HM, Long Y, Zhang XX, Zhong L, Deng L, Chen XH, Li XQ: Mesenchymal stem cells transplantation mildly ameliorates experimental diabetic nephropathy in rats. Chin Med J (Engl) 2009;122:2573-2579.

>38 Kretlow JD, Jin YQ, Liu W, Zhang WJ, Hong TH, Zhou G, Baggett LS, Mikos AG, Cao Y: Donor age and cell passage affects differentiation potential of murine bone marrow-derived stem cells. BMC Cell Biol 2008;9:60.

-39 Duscher D, Rennert RC, Januszyk M, Anghel E, Maan ZN, Whittam AJ, Perez MG, Kosaraju R, Hu MS, Walmsley GG, et al: Aging disrupts cell subpopulation dynamics and diminishes the function of mesenchymal stem cells. Sci Rep 2014;4:7144.

40 Wang SS, Ren J: Aging as an essential modifier for the efficacy in mesenchymal stem cell therapy through an inositol phosphate $6 \mathrm{ki}$ nase-inositol pyrophosphate 7-dependent mechanism. Stem Cell Res Ther 2014;5:43.
41 Heeschen C, Lehmann R, Honold J, Assmus B, Aicher A, Walter DH, Martin H, Zeiher AM, Dimmeler S: Profoundly reduced neovascularization capacity of bone marrow mononuclear cells derived from patients with chronic ischemic heart disease. Circulation 2004;109:1615-1622.

42 Drewa T, Joachimiak R, Kaznica A, Flisinski M, Brymora A, Manitius J: Bone marrow progenitors from animals with chronic renal failure lack capacity of in vitro proliferation. Transplant Proc 2008;40:1668-1673.

43 Yamada A, Yokoo T, Yokote S, Yamanaka S, Izuhara L, Katsuoka Y, Shimada Y, Shukuya A, Okano HJ, Ohashi T, et al: Comparison of multipotency and molecular profile of MSCs between CKD and healthy rats. Hum Cell 2014;27:59-67.

44 Zhang Y, McNeill E, Tian H, Soker S, Andersson KE, Yoo JJ, Atala A: Urine derived cells are a potential source for urological tissue reconstruction. J Urol 2008;180:2226-2233.

45 Bharadwaj S, Liu G, Shi Y, Wu R, Yang B, He T, Fan Y, Lu X, Zhou X, Liu H, et al: Multipotential differentiation of human urine-derived stem cells: potential for therapeutic ap plications in urology. Stem Cells 2013;31: 1840-1856.

46 Ouyang B, Sun X, Han D, Chen S, Yao B, Gao Y, Bian J, Huang Y, Zhang Y, Wan Z, et al: Human urine-derived stem cells alone or genetically-modified with FGF2 improve type 2 diabetic erectile dysfunction in a rat model. PLoS One 2014;9:e92825.

47 Takahashi K, Yamanaka S: Induction of pluripotent stem cells from mouse embryonic and adult fibroblast cultures by defined factors. Cell 2006;126:663-676.

48 Takahashi K, Tanabe K, Ohnuki M, Narita M, Ichisaka T, Tomoda K, Yamanaka S: Induction of pluripotent stem cells from adult human fibroblasts by defined factors. Cell 2007; 131:861-872.

49 Xia Y, Nivet E, Sancho-Martinez I, Gallegos T, Suzuki K, Okamura D, Wu MZ, Dubova I, Esteban CR, Montserrat N, et al: Directed differentiation of human pluripotent cells to ureteric bud kidney progenitor-like cells. Nat Cell Biol 2013;15:1507-1515.

50 Lam AQ, Freedman BS, Morizane R, Lerou $\mathrm{PH}$, Valerius MT, Bonventre JV: Rapid and efficient differentiation of human pluripotent stem cells into intermediate mesoderm that forms tubules expressing kidney proximal tubular markers. J Am Soc Nephrol 2014;25: 1211-1225.

51 Taguchi A, Kaku Y, Ohmori T, Sharmin S, Ogawa M, Sasaki H, Nishinakamura R: Redefining the in vivo origin of metanephric nephron progenitors enables generation of complex kidney structures from pluripotent stem cells. Cell Stem Cell 2014;14:53-67.

52 Song B, Smink AM, Jones CV, Callaghan JM, Firth SD, Bernard CA, Laslett AL, Kerr PG, Ricardo SD: The directed differentiation of human iPS cells into kidney podocytes. PLoS One 2012; 7:e46453.
53 Yu J, Vodyanik MA, Smuga-Otto K, Antosiewicz-Bourget J, Frane JL, Tian S, Nie J, Jonsdottir GA, Ruotti V, Stewart R, et al: Induced pluripotent stem cell lines derived from human somatic cells. Science 2007;318:1917-1920.

54 Aasen T, Raya A, Barrero MJ, Garreta E, Consiglio A, Gonzalez F, Vassena R, Bilic J, Pekarik V, Tiscornia $\mathrm{G}$, et al: Efficient and rapid generation of induced pluripotent stem cells from human keratinocytes. Nat Biotechnol 2008;26:1276-1284.

55 Haase A, Olmer R, Schwanke K, Wunderlich S, Merkert S, Hess C, Zweigerdt R, Gruh I, Meyer J, Wagner S, et al: Generation of induced pluripotent stem cells from human cord blood. Cell Stem Cell 2009;5:434-441.

56 Song B, Niclis JC, Alikhan MA, Sakkal S, Sylvain A, Kerr PG, Laslett AL, Bernard CA, Ricardo SD: Generation of induced pluripotent stem cells from human kidney mesangial cells. J Am Soc Nephrol 2011;22:1213-1220.

57 Zhou T, Benda C, Duzinger S, Huang Y, Li X, Li Y, Guo X, Cao G, Chen S, Hao L, et al: Generation of induced pluripotent stem cells from urine. J Am Soc Nephrol 2011;22:1221-1228.

58 Zhou T, Benda C, Dunzinger S, Huang Y, Ho JC, Yang J, Wang Y, Zhang Y, Zhuang Q, Li $Y$, et al: Generation of human induced pluripotent stem cells from urine samples. Nat Protoc 2012;7:2080-2089.

59 Rogers I: Induced pluripotent stem cells from human kidney. J Am Soc Nephrol 2011;22: 1179-1180.

60 Park IH, Arora N, Huo H, Maherali N, Ahfeldt T, Shimamura A, Lensch MW, Cowan C, Hochedlinger K, Daley GQ: Disease-specific induced pluripotent stem cells. Cell 2008;134: 877-886.

61 Maehr R, Chen S, Snitow M, Ludwig T, Yagasaki L, Goland R, Leibel RL, Melton DA: Generation of pluripotent stem cells from patients with type 1 diabetes. Proc Natl Acad Sci USA 2009;106:15768-15773.

62 Freedman BS, Lam AQ, Sundsbak JL, Iatrino R, Su X, Koon SJ, Wu M, Daheron L, Harris PC, Zhou J, et al: Reduced ciliary polycystin-2 in induced pluripotent stem cells from polycystic kidney disease patients with PKD1 mutations. J Am Soc Nephrol 2013;24:1571-1586.

63 Thatava T, Armstrong AS, De Lamo JG, Edukulla R, Khan YK, Sakuma T, Ohmine S, Sundsbak JL, Harris PC, Kudva YC, et al: Successful disease-specific induced pluripotent stem cell generation from patients with kidney transplantation. Stem Cell Res Ther 2011; 2:48.

64 Chen W, Huang J, Yu X, Lin X, Dai Y: Generation of induced pluripotent stem cells from renal tubular cells of a patient with Alport syndrome. Int J Nephrol Renovasc Dis 2015; 8:101-109.

65 Lian Q, Zhang Y, Zhang J, Zhang HK, Wu X, Zhang Y, Lam FF, Kang S, Xia JC, Lai WH, et al: Functional mesenchymal stem cells derived from human induced pluripotent stem cells attenuate limb ischemia in mice. Circulation 2010;121:1113-1123. 
66 Araki R, Uda M, Hoki Y, Sunayama M, Nakamura M, Ando S, Sugiura M, Ideno H, Shimada A, Nifuji A, et al: Negligible immunogenicity of terminally differentiated cells derived from induced pluripotent or embryonic stem cells. Nature 2013;494:100-104.

-67 Sun YQ, Deng MX, He J, Zeng QX, Wen W, Wong DS, Tse HF, Xu G, Lian Q, Shi J, et al: Human pluripotent stem cell-derived mesenchymal stem cells prevent allergic airway inflammation in mice. Stem Cells 2012;30: 2692-2699.

-68 Fu QL, Chow YY, Sun SJ, Zeng QX, Li HB, Shi JB, Sun YQ, Wen W, Tse HF, Lian Q, et al: Mesenchymal stem cells derived from human induced pluripotent stem cells modulate $\mathrm{T}$ cell phenotypes in allergic rhinitis. Allergy 2012;67:1215-1222.

69 Caplan AI, Dennis JE: Mesenchymal stem cells as trophic mediators. J Cell Biochem 2006;98:1076-1084.

-70 Wu HJ, Yiu WH, Li RX, Wong DW, Leung JC, Chan LY, Zhang Y, Lian Q, Lin M, Tse HF, et al: Mesenchymal stem cells modulate albumin-induced renal tubular inflammation and fibrosis. PLoS One 2014;9:e90883.

71 Park JH, Hwang I, Hwang SH, Han H, Ha H: Human umbilical cord blood-derived mesenchymal stem cells prevent diabetic renal injury through paracrine action. Diabetes Res Clin Pract 2012;98:465-473.
72 Volarevic V, Arsenijevic N, Lukic ML, Stojkovic M: Concise review: mesenchymal stem cell treatment of the complications of diabetes mellitus. Stem Cells 2011;29:5-10.

-73 Aurora AB, Olson EN: Immune modulation of stem cells and regeneration. Cell Stem Cell 2014;15:14-25.

74 Bernardo ME, Fibbe WE: Mesenchymal stromal cells: sensors and switchers of inflammation. Cell Stem Cell 2013;13:392-402.

75 Bi Y, Stuelten CH, Kilts T, Wadhwa S, Iozzo RV, Robey PG, Chen XD, Young MF: Extracellular matrix proteoglycans control the fate of bone marrow stromal cells. J Biol Chem 2005;280:30481-30489.

76 Kume S, Kato S, Yamagishi S, Inagaki Y, Ueda S, Arima N, Okawa T, Kojiro M, Nagata K: Advanced glycation end-products attenuate human mesenchymal stem cells and prevent cognate differentiation into adipose tissue, cartilage, and bone. J Bone Miner Res 2005; 20:1647-1658.

77 Ishizuka T, Hinata T, Watanabe Y: Superoxide induced by a high-glucose concentration attenuates production of angiogenic growth factors in hypoxic mouse mesenchymal stem cells. J Endocrinol 2011;208:147-159.

78 Secchiero P, Melloni E, Corallini F, Beltrami AP, Alviano F, Milani D, D’Aurizio F, di Iasio MG, Cesselli D, Bagnara GP, et al: Tumor necrosis factor-related apoptosis-inducing ligand promotes migration of human bone marrow multipotent stromal cells. Stem Cells 2008;26:2955-2963.
79 Gordin D, Soro-Paavonen A, Thomas MC, Harjutsalo V, Saraheimo M, Bjerre M, Forsblom C, Flyvbjerg A, Groop PH; FinnDiane Study Group: Osteoprotegerin is an independent predictor of vascular events in Finnish adults with type 1 diabetes. Diabetes Care 2013;36:1827-1833.

80 Brosius FC 3rd, Alpers CE, Bottinger EP, Breyer MD, Coffman TM, Gurley SB, Harris RC, Kakoki M, Kretzler M, Leiter EH, et al: Mouse models of diabetic nephropathy. J Am Soc Nephrol 2009;20:2503-2512.

81 Alpers CE, Hudkins KL: Mouse models of diabetic nephropathy. Curr Opin Nephrol Hypertens 2011;20:278-284.

82 Hudkins KL, Pichaiwong W, Wietecha T, Kowalewska J, Banas MC, Spencer MW, Muhlfeld A, Koelling M, Pippin JW, Shankland SJ, et al: BTBR Ob/Ob mutant mice model progressive diabetic nephropathy. J Am Soc Nephrol 2010;21:1533-1542.

83 Humphreys BD, Czerniak S, DiRocco DP, Hasnain W, Cheema R, Bonventre JV: Repair of injured proximal tubule does not involve specialized progenitors. Proc Natl Acad Sci USA 2011;108:9226-9231.

84 Okita K, Nakagawa M, Hong HJ, Ichisaka T, Yamanaka S: Generation of mouse induced pluripotent stem cells without viral vectors. Science 2008;322:949-953. 